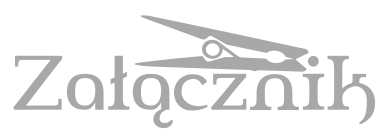

\title{
GOMBROWICZ'S KITSCH IN THE CONTEXT OF (POST)MODERNITY THEORY
}

DAGMARA JASZEWSKA

Department of Theology,

Cardinal Stefan Wyszyński University in Warsaw djaszewska@wp.pl

Kitsch has probably existed since time immemorial, or at least as long as the division into higher and lower classes, the aristocracy and the commoners and since the former have been trying to cut themselves off from the latter, whereas the latter have been aspiring, copying and pretending... Yet kitsch is also, to a certain extent, the child of modernity. Ideal conditions for it were born in the $20^{\text {th }}$ century: on the one hand, there was easy industrial production, offering tons of plastic trinkets; on the other, progressing democratization of life and, along with it, the temptation to take into account, in the creation and reception of art, the principle of the 'common denominator'. At the beginning of the $20^{\text {th }}$ century, marked by the flourish of tacky and superficial aesthetization in the mass culture, criticism of kitsch intensified (see: Ortega y Gasset 1932; Macdonald 1953). First and foremost, modernism - reigning at least until the middle of the $20^{\text {th }}$ century - with its obsession of 'high art' and 'high artist', which was accompanied by the pressure for innovation and originality - allowed such philosophers as Hermann Broch or Theodor Adorno to repudiate kitsch as a stereotype, banality, a caricature of art, bad art or false $\operatorname{art}^{1}$.

Nowadays, in the late-modern times (or, if preferred, the post-modern times), it no longer behooves to stigmatize kitsch: criticism of kitsch is

1 In Adorno's (1997) case, this was the avant-garde with the category of grandeur discovered anew. On the other hand, Broch's (1969) concept was more universalist - it assumed ties between aesthetics and ethics and saw the role of art in searching for authenticity of artistic expression, identifying it with the search for truth. 
rather placed within the walls - destroyed a long time ago - of obstinate and proud modernity ${ }^{2}$. Contemporary art was particularly conducive to this: the accomplishments of late avant-garde (in particular pop-art, which put a mark of equality between art and mass culture banality) provoked discussions about the end of art and the end of aesthetics (see: Piątkowski 2008; Sekuła 2008). On the other hand, kitsch is especially justified today because modernity has not ended but, on the contrary, its symptoms (homogenization and democratization of culture) have greatly intensified, resulting in further blurring of the borders between 'high art' and 'low art'. All of this has contributed to the post-modernist conviction of crisis and devaluation of high culture, of the lack of criteria for 'true art' at the times of commonplace aesthetization (see: Dziamski 1995).

I believe that today it is impossible to speak about kitsch without referring to the philosophical and cultural reflection on modernity. What is more, whilst analyzing the subject matter of kitsch in the works of Witold Gombrowicz, it is also worthwhile to locate the issue in the context of the writer's attitude to modernity ${ }^{3}$. Fortunately, this task is not ungrateful, as we are talking about a philosophizing artist, an artist who may easily be called a philosopher of modernity (see: Cataluccio, Illg 1991) ${ }^{4}$. By undertaking the issue of kitsch in Gombrowicz's works in this article, I remain in the circle of his concept of modernity and I am trying to reconstruct its certain features.

2 Richard Shusterman (1992) excellently reconstructs the modernist concept of art with its elitist nature (in order to subject it to criticism from the point of view of neo-pragmatism).

3 Jerzy Jarzębski (1996) was the first to refer to the issues of modernism and post-modernism by mentioning the theme of kitsch in Gombrowicz's works.

${ }^{4}$ It has turned out in the course of time that Gombrowicz's concept of art (and life) is so acute, deep and far-reaching that it was later successfully compared to various ideas which subsequently described the cultural situation of post-war Europe. Therefore, Gombrowicz was considered the prophet of structuralism, existentialism and post-modernism; from the perspective of time, it may even be said: reflection on modernity and the so-called late modernity (post-modernity). 


\section{GOMBROWICZ'S STRUGGLE WITH KITSCH: BETWEEN MODERNISM AND POST-MODERNISM}

Jerzy Jarzębski has justly noticed that Gombrowicz is straddling between two epochs and may be ascribed the features of both a modernist and a post-modernist: 'still »avant-garde«, still believing in the clear "progress" in the realm of art, literature and music, but already induced to parody, distance, playing with the form, already mocking the orthodox followers of the avant-garde doctrine' (Jarzębski 1996: 69). The critic adds that it is possible to interpret the work of the author of Ferdydurke either in a more modernist or a post-modernist manner, emphasizing, as the case may be, discoveries and new creative concepts or the diversity and inconsistency of the presented ideas, a desire for inferiority, experiments with the form, as well as a tendency to break it. In the first case, Gombrowicz rather criticizes (parodies) kitsch, in the second, he plays with it, and even 'produces it' (ibid.).

Even if Gombrowicz was a modernist, he was no longer a believer ${ }^{5}$. In spite of displaying a modernist longing for Great Art, Gombrowicz's fight for greatness rather resembles the idea of the 'strong poet' Rorty - who is a philosopher considered a post-modern thinker (see: Szahaj 2002: 188-208) - a figure trying (similarly to the 'liberal ironist') to get by in the era of contingency. According to Rorty (1989), grandeur and originality, not giving in to 'other vocabularies' are a tragically difficult task in the modern times (see: Kwiek 1993: 57).

If Gombrowicz was, however, a post-modernist, he was not a 'believer' either i.e. not a post-modernist who enjoyed the multitude, chaos and confusion. He rather suffered due to the failure to speak 'as one ought to'. Therefore, the phrase 'between modernism and post-modernism' from the title does not entail varying proportions of these ideas in the writer's thought, but the fact that also this time he managed to get away from ideologies, even though the anxiety governing them affected him.

${ }^{5}$ I think that one may even argue with Jarzębski's thesis that the writer 'still believed in progress' even in the realm of art, by recalling the words of the writer: 'Me, a non-believer?' (Gombrowicz 1988). This testifies to the writer's criticism towards the accomplishments of contemporary avant-garde; anyway, Jerzy Jarzębski (1996: 56) finds 'derision of avant-garde poetry' in Ferdydurke. 
In any case, even though 'Great Form' still remained only a postulate and a dream, Gombrowicz at least knew what was not it, and continually rejected and degraded it. These attacks at the form may be described as attacks at kitsch. In his excellent study, Jarzębski (1996: 57) discussed a number of examples of Gombrowicz's 'represented kitsch'. The writer ruthlessly ridicules the existing social forms, showing the stereotypical, clichéd, preposterous and fake nature of his characters, which is difficult to bear. Failed human forms simply turned out to be unaesthetic: either insufficient, too flat, superficial and ugly (like the social form of aristocrats from the short-story Banquet at Countess Kottubaj's) or, on the contrary: too slick and smooth, too 'pretty' (Zosia from Ferdydurke), too immature and infantile (Zuta from the same novel), but primarily too mature, with pretences to grandeur (Lawyer Kraykowski). Therefore, Gombrowicz criticized everyday customary kitsch as 'bad art' like a typical modernist. At this moment, he could shake hands with Adorno and Broch - criticism of kitschy forms is a gesture of the modernist Reason, setting high requirements of originality, authenticity, solemnity and selflessness for art.

Yet, in contrast to the above-mentioned philosophers, Gombrowicz no longer has a deck of aces in his hand, he is unable to show what is perfect and, therefore, what is not kitschy. Thus, this is the place where the writer's 'modernism' ends and the post-modern condition begins. His alter ego, Joey from Ferdydurke, is trying to create a mature and brilliant (not kitschy) work, but is incapable of that. Why is it so difficult to be serious today, to write another 'work of high culture'? As Gombrowicz (2000: 4) autobiographically recollects in Ferdydurke: 'So why did my pen betray me? Why did holy shame forbid me to write a notoriously trivial novel? Instead of spinning lofty themes from the head, from the soul, I spun the themes from more lowly quarters?'.

Thus, why doesn't Gombrowicz want to write 'yet another novel about love' (ibid.: 10)? Let us notice that the tendency for kitsch ceases to be the vice of an individual artist - it becomes the curse of the epoch in which 'everything had already been created'. It is the same situation as in the wellknown passage from correspondence between Umberto Eco and Stefano 
Rosso - one cannot simply write today: 'I love you desperately'. In this epoch, faith becomes naivety and truth becomes kitsch as everything that is lofty also seems to turn into kitsch (like Miętus' solemn face in the famous duel of grimaces). Eternal Works, placed on display in museums and schools, are dead. They are no longer palpable, nobody experiences them ('Nobody can read more than two or three verses. Oh God! I cannot...' [Gombrowicz 2000: 44]), they may potentially be used to lift the spirits of the nation and yet such instrumental use contradicts the modernist idea of aesthetic contemplation.

Nota bene, all of Gombrowicz's exposing and destructive intentions should rather be called 'holy wrath' (here, even the figure of Jesus Christ throwing merchants out of the temple would be fitting) than believed to be an example of 'attacks at holiness' (and result in removal of their author from the list of required reading). By showing the kitschy nature of religion, patriotism and other values, Gombrowicz does not reject Truth or Beauty, but only their caricatures, the easiness of their substitutes in the era of 'readymade objects'. Following this trail of thought, the contemporary young conservatives related to the Church are even searching for similarities between the thoughts of Gombrowicz and Cardinal Stefan Wyszyński ${ }^{7}$, which is rather back-breaking, but true in a sense that Gombrowicz was

6 'For me, the postmodern attitude is that of a man who loves a woman who is intelligent and well-read: he knows that he cannot say today »I love you desperately" because he knows (and she knows that he knows) that that is a line out of Barbara Cartland. Yet there is a solution. He can say: "As Barbara Cartland would say, I love you desperately«. At this point, he has avoided the pretence of innocence, he has clearly affirmed that no one can speak in an innocent mode; but he has still told the woman what he wished to tell her - that he loves her, but in the age of lost innocence' (Rosso 1983: 2-3).

7 The entire issue 34 of magazine „Pressje” from 2013 was devoted to this subject matter (title of the issue: 'Polish form'). Editors of the volume criticise the simplified and strongly solidified (even in the Third Republic of Poland) opposition of the traditional, coarse 'Polish form', personified by Cardinal Wyszyński, with Gombrowicz's freedom and modernity, proving, contrary to common interpretations, that these two Poles were united by a number of joint ideals. See in this issue: Rojek 2013; Lubelski 2013. 
longing for Truth and Beauty in the same way as Catholics and other believers; he was not satisfied with the dwarfish form of these values8.

Thus, Gombrowicz was a modernist (though a disbelieving modernist) to a degree in which he was still longing for the 'Great Form' and criticized the immature forms. He was also a post-modernist, but eventually everything that was ever written by him (and he claimed that he never knew what he would write [see: Cataluccio, Illg 1991: 27]), turned out to be a parody, a pastiche, and thus, in fact, 'working with remainders.' Hence, his fight against kitsch was also post-modernist. Yet this was not a strategy which he would proclaim or recommend, as militant post-modernists did. He was closer to believing in art as an 'unfinished project'.

Therefore, what was offered in exchange - if Gombrowicz did not propose any new forms to replace the destroyed ones? Well: Immaturity. Jarzębski noted justly that even though it is possible to identify kitsch with Immaturity in a simplistic mode, yet, it is definitely closer to the form, to maturity 9 . Kitsch may constitute immature art (unfinished, infantile and simplistic), but at the same time Gombrowicz's Immaturity is not kitschy: it is deadly serious. Gombrowicz reverses the logic by showing that Immaturity is mature (because it is honest and self-reflective), whereas Maturity is kitschy and false. This is immaturity (after) maturity: it corresponds to the post-

8 There are also interpretations of Gombrowicz's philosophy in the categories of a search for the sacred, see: Lubelski 2015.

9 Jarzębski (1996: 55-56) accurately positions the phenomenon of kitsch between the dichotomies of key importance for Gombrowicz: 'Form and chaos, Maturity and Immaturity, Superiority and Inferiority, Old Age and Youth'. Yet first and foremost, he draws attention to the fact that kitsch escapes simple categorising. Definitely - he notices - it is impossible to put kitsch on the one side of the barricade in Gombrowicz's works and 'high' or 'mature' art on the other side. This results from ambiguity of terms that Gombrowicz used. He writes: 'If kitsch was meant to be the immature art, not thought-through and unrefined, then - obviously - it would be located somewhere in the vicinity of Youth and Immaturity; definitely on the one side of the aforementioned axis dividing the world. If it was a naive "art of happiness" pampering our primitive tastes and bashful dreams - it would also be fully located on this side. However, if we simply consider it art of little value, because it relies on stereotypes and clichés, it would turn out that it is easier to find its place on the side of Maturity and Form'. 
-modernist version 'I know that I know nothing' or 'vanitas vanitatum'; it is sheer potency or even an act of humiliation - it is silence. Difficult, if not unattainable (continually succumbing into forms), it is a fulfillment of Ernest Gellner's (1992: 47) prophecy: if everything has already been created, postmodernists should remain silent.

\section{GOMBROWICZ'S 'LOVE AFFAIR WITH KITSCH' (TOWARDS POST-MODERNITY)}

By referring to the title mentioned in Jarzębski's essay, I would like to take a look at the second part of Gombrowicz's ambivalent attitude to kitsch (even though obviously these two aspects, namely criticism and use of kitsch, may be analyzed separately with difficulty only and to the detriment of the interpretation of the whole).

Why does Gombrowicz reach for kitsch, and why - as Jarzębski (1996: 69) writes - is he - in a post-modernist mode - more of its producer than a critic? Gombrowicz's obsession with Inferiority is undoubtedly of fundamental importance here. It might be explained with the use of psychoanalysis, it might be considered an original idiosyncrasy - but it also has its justification in the approaching culture of late modernity. It encompasses a number of notions for Gombrowicz.

First of all, there is the love for the actual 'lower classes'. Here, the writer anticipated the surprising democratization of culture of our times. Joey from Ferdydurke perversely falls in love with farm-hands, schoolgirls and peasants: he loves inferiority, greenness, opacity. The 'low' content even has certain advantage over the 'high' content: there is no pretence here, no tiring aspiration. The drive towards inferiority is also a kitschy gesture of members of intelligentsia tired with their superiority, tempted by the democratic epoch. It has already appeared in the fascination of Young Poland's artists with peasants and was shyly expressed in Ferdydurke in the desire to 'fraternize' with a farm-hand.

Secondly, Inferiority denotes youth. Gombrowicz was not hailed as the prophet of the youth revolution of the 1960s not for nothing. The Elderly, bowing to the Younger, is still hiding in Gombrowicz's works; in Ferdydurke he secretly writes letters to the Modern Schoolgirl. Thus, at some point in time, the attraction to youth was a bashful thing; this fascination was, however, not an obstacle in realizing Superiority on a daily basis - by acting 
in a Mature manner. Today, we can clearly see the 'helplessness' of wise men towards youthful beauty and freshness (vide blight of film directors who were charmed by youth, for example Krzysztof Zanussi, who hired the Polish celebrity Doda, or even Woody Allen, who was enchanted by the quite primitive beauty of Scarlett Johansson; unfortunately, in their case, as opposed to Gombrowicz, their kitsch is rather unwitting...). In the era of late modernity, stately, mature and elitist wise men no longer gain high positions; we are dealing with the abuse of mass culture, present already during the times of Witkacy (Witkiewicz 1980), who was complaining about the omnipresent radio, raping people's ears.

Thirdly, Inferiority means the furtive secrets of the soul (and the body). Gombrowicz, constantly reminding us about the split, about the dark side of the soul, about the 'sub-official' (yet not as something that has to be overcome, quashed, but something that has a right to exist, similarly like a child or a youth in an adult person), creates an area where the rehabilitation of kitsch is possible. This is also one of the aspects of Immaturity in Gombrowicz's works: the sphere of instinct and desire in man, naked corporeality, everything that has been 'sucked from more lowly quarters'. Here, Gombrowicz is revolutionary. As Jarzębski (1996: 62) notices, the writer started his very career with such threads; however, he destroyed his first works under the impact of terror which they evoked in their readers. Eventually, Gombrowicz did not have the courage to fully give in to his coy desires and satisfied himself with a 'love affair with kitsch'. In this context, Jarzębski discusses the novel Opętani (Possessed), created as an intended mass culture product, as well as an earlier attempt at writing a purposefully 'bad novel' (ibid.: 54). Today, we would call them post-modernist strategies: the double layer of Gombrowicz's novel evokes associations with the prose of Umberto Eco, becomes a play with inferiority and, at the same time, a living proof of the post-modernist blurring of the borders between high and low art. Other strategies of a 'love affair with kitsch' include, for example, a pastiche, mixing of genres, quotations, motives taken from second-class literature, combined with references to high art, as listed by Jarzębski (1996: 62). Gombrowicz, like a typical post-modernist, mixes and blurs the borders, plays with kitsch.

Fourthly: the child. Sometimes the writer straightforwardly calls for the child by asking how adult roles refer to the concept of 'the child runs 
deep' and whether some repression has not accidentally taken place here ${ }^{10}$. Many decades before the advent of 'child studies', Gombrowicz remains close to the general post-modernist aura of 'lack of seriousness', conceding to being childish and infantile and demanding the right to play (for example visible in the soft spot that most modern people have for gadgets of mass culture [Sekuła 2008: 43]).

Thanks to the obsession with Inferiority, a clearly post-modernist landscape is created: nothing is clear or separate any more: high and low, art and kitsch; modernist aesthetics will not return. Today, these divisions are no longer valid also thanks to Gombrowicz (2000: 9), who 'was duly anointed by the lower class at the outset', sensitive to the charms of mass culture, the temptations of democratization of culture.

Yet on the other hand, Gombrowicz not so much 'plays with kitsch', but rather treats it very seriously. Jarzębski (1996: 53-54) claims that kitsch is not only a humorous 'seasoning' of his works, but a 'fixed element of his philosophy of artistic activities'. The artist confesses his desire for inferiority as an attempt of 'making this confession a foundation and evidence for authenticity of own art' (ibid.). He not so much joyfully gives in to the delight of kitsch, 'the art of happiness' (Moles 1978), he rather does it in a gesture of desperate honesty. Absolute frankness, soul searching and... kitsch: all of this comes to the surface, as it is 'a part of us'

The second, apart from a desire to Inferiority, cause of Gombrowicz's inclination to kitsch appears here, namely jealousy. When Gombrowicz

${ }_{10}$ 'No, not a word about their own lives - only about the lives of bee-keepers. Indeed, having produced twenty books on the lives of bee-keepers, one can be immortalised - but what is the connection, where is the bond between the king of bee-keepers and the inner man, between the man and the youth, between the youth and the boy, the boy and the child that, after all, he once was, what comfort is the king to the little brat in you? A life unmindful of these bonds, a life that does not evolve in unbroken continuity from one phase to the another is like a house built from the top down, and must inevitably end in a schizophrenic split of the inner self' (Gombrowicz 2000: 5).

11 Jerzy Jarzębski (1996) devotes a lot of attention in his essay to Gombrowicz's peculiar anthropology, from which it follows that kitsch is close to man's nature; therefore, it is difficult to run away from it. 
confesses his love for Inferiority, when he submerges for a moment in its depths, he forgets about Superiority, to which he is also pretending. However, when he remembers about it, when he makes the gesture of mocking the Form, of seeing through, ridiculing, 'contaminating' and rejecting cheap kitsch, he is always accompanied by an unwanted friend - jealousy, and even envy. Obviously, they are justified due to the fact that Gombrowicz once again honestly confesses his sins and thus neutralizes them (Jarzębski 1996: 65-66).

Jealousy is caused by the fact that the only alternative for the rejected Forms - succumbing to Immaturity - means an uncomfortable situation. Conceding to it equals social degradation, even if this is philosophical 'immaturity after maturity.' Immaturity is not accepted in the society (nobody differentiates it from ordinary immaturity, underdevelopment). Therefore, the main character of 'Ferdydurke' envies others.... kitsch. He envies the courage of these people who decided to say SOMETHING instead of being silent (in particular when they managed to do it quite well). Joey is tormented with his 'post-modern condition' and confesses that he is fed up with remaining in the situation of suspension, insecurity and non-authenticity. Acknowledging one's own immaturity is, in fact, an act of humility, to which Gombrowicz never really wanted to concede in his life, hoping (quite justly) that he would eventually develop his own great Style and Form.

Meanwhile, Gombrowicz's jealousy is put in inverted commas, because in reality, there is nothing to be jealous of - the writer only wishes to complain that the condition of immaturity is difficult. This happens when Gombrowicz's character envies, to a certain degree, all the mature, even primitive, cultural aunts. The attack launched against the opinions of the cultural aunts ${ }^{12}$ is not only a satire attacking poseurs, clever dodgers attaching themselves

12 'Indeed, world culture has been beset by a flock of superfluous hens patched-on, pinned-on, to literature, who have become finely tuned to spiritual values and well versed in aesthetics, frequently entertaining views and opinions of their own, who have even caught on to the notions that Oscar Wilde is passé and that Bernard Shaw is a master of paradox. Oh, they are on to a fact that they must be independent, profound, unobtrusively assertive, and filled with auntie kindliness' (Gombrowicz 2000: 6). 
to things that do not belong to them, painfully inauthentic, superficial, who only derive trite clichés from the accomplishments of humanity and impress others with them (like the New York snobs from Woody Allen's comedies). This is also envy of those who cope well in this thicket, who have mastered the art of surfing or patching the holes (or transversality - as Wolfgang Welsch [1998] calls this ability flatteringly), who are not afraid of the multitude and accidental nature of own judgments and choices.

It is already at this moment that the use of seemingly simple satire marks the beginning of Gombrowicz's 'love affair with kitsch'. The writer stigmatizes it not with a feeling of superiority, like modernists did, but - even when he lays kitsch bare - as Jarzębski noted - he does it in a kitschy manner ${ }^{13}$. Gombrowicz parodies 'from the inside' and is 'soiled' by the modern mass culture and seduced by its charm. Therefore, when stigmatizing kitsch, he succumbs to it; he cannot remain at a distance - thence, the desperate strategies of 'messing up the compote' and spying on the Modern Schoolgirl. According to Jarzębski (1996: 60), kitsch in Ferdydurke was ridiculed, but not disarmed. Gombrowicz only neutralises it, conceding to his own weakness.

However, Joey sometimes 'envies' no longer with a grain of salt; at times, he envies for real, because the shapeliness of kitsch, even its prettiness and unity is a great temptation as opposed to the conscious lack of form... Gombrowicz is aware of the beauty of kitsch, because youth and kitsch often entail attractiveness and beauty.

${ }^{13}$ For example, in the short-story entitled Banquet at Countess Kottubaj's, which parodies the kitsch of aristocracy, the narrator plays a stock role of 'a simpleton among the high society'; the writer himself is stuck inside the kitschy characters that he parodies; see: Jarzębski 1996: 58. 


\section{GOMBROWICZ AS A PROPHET OF THE AESTHETIZATION OF THE CULTURE ${ }^{14}$}

Truth is not a matter of arguments. It is only a matter of attraction, that is, a pulling toward. Witold Gombrowicz, Diary 1953-1956.

In the modernist concepts mentioned at the beginning of the paper, the greatest enemy of art and, at the same time, the synonym of kitsch, is aesthetization. In particular for Hermann Broch (1996), who assumed ties between aesthetics and ethics, aesthetization - understood as the requirement of 'working beautifully' instead of 'working well' - is a fraud, a chase after effects (flashiness), instead of looking for the truth (as art should). A fraudulent - because over-aesthetized - work of art does not offer fulfillment. It replaces true feelings with a superficial substitute, cheap entertainment.

Meanwhile, aesthetization is a phenomenon that is the quintessence of modern culture. And if aesthetization is the other name of kitsch, it means that we are living at the time of its dictatorship. Even Wolfgang Welsch (1997), a philosopher related to post-modernism, theoretician of aesthetization and, at the same time, a critic of its most vulgar and primitive dimension - common beautification of everything, the 'gilding' and the 'glossing' of knobs, garbage bins, stores, streets, etc. - agrees with it. The philosopher calls this phenomenon a superficial aesthetization and identifies it with kitsch. He uses the appeal for the 'culture of the blind spot' against it; he attracts attention to the threat of anaesthetization (reverse of aesthetization), which causes insensitivity to stimuli and to beauty resulting from over-saturation with universal prettiness.

Until this moment, Welsch retains his modernist ideas: he rejects kitsch as cheap fraud. But also, similarly to Gombrowicz, he is not completely immune to the power of beautification embedded in the modern culture. He moves to the side of post-modernism when he announces the victory of aesthetics over ethics and designates a very important place to aesthetics in the modern hierarchy of values (in the situation of the post-modernist crisis of Reason).

${ }^{14}$ I earlier discussed certain threads mentioned here; see: Jaszewska 2002. 
Another theoretician of modern aesthetization, Richard Shusterman (1992), acts similarly by proclaiming that with respect to the horror vacui that has been left after the fallen Great Narratives, we cannot disdain the aesthetic criteria. Therefore, Welsch (1997) calls aesthetics the first modern philosophy. And that is why he is looking for a deeper theory of aesthetization, combining it with the mass media pervading our world, with the flexibility of visual culture and finally with the condition of the new man, homo aestheticus, whose life is guided by form and aesthetic criteria. Here, aesthetization consists of commonplace stylization which is, to a certain extent, a parody of the Nietzschean 'create thyself' (let us notice: in the past, women simply dressed, nowadays, they are choosing their styling). It is not without sarcasm that Welsch writes that in a situation when moral cannons collapse, one may at least impress others with knowledge how to properly choose wine glasses for dinner. The power of taste: this is something that should not be disdained in times when 'meta-narratives have collapsed.' The following statement of Gombrowicz (2000: 148) is a great match for the above:

Nothing that is really tasty can be really awful (just like the word 'tasty' indicates), and only that which has bad taste is truly inedible. (...) So why does busybody of a woman, who uses her finger to tear at the most bloody social ills, death by starvation of a worker's family of six, why, I ask, does she not dare, with the same finger, to pick her ear in public? Because this would have been much more dreadful. Death from starvation, or the death of a million in war - this can be eaten, even relished - yet there still exists in this world combinations that are not edible, that make us vomit, that are bad, discordant, and repellent, oh, even satanic, and these the human organism rejects. And yet our first and foremost task is to relish, we must relish, relish, let the husband, wife, and children lie dying, let our heart be torn to shreds, as long as it's done tastefully, yes, tastefully!

Similarly to Welsch, Gombrowicz is critical towards this form of aesthetization of ethics. It may also be said that just as Welsch, he notices the meagerness and primitivism of superficial aesthetization. In A Kind of Testament this is how he comments on the motive of Modern Schoolgirl:

For example: the ideal of feminine beauty in Ferdydurke, its Venus, is the 'Modern Schoolgirl' with her fascinating calves (...). Ferdydurke is full 
of such immature ideals, myths of inferior quality, such second-class beauty, cheap charms, doubtful allure... (Gombrowicz 2007: 62).

And thus: immaturity, tackiness, kitsch! At the same time, there is a certain small perfection, like a Christmas tree and snow caught in a glass, an ideally round sphere, soothing the head and the heart of a modern intellectual. This is where the ambivalence of both philosophers begins. Welsch, willingly or not, concedes that knowledge about wine glasses is not to be discredited and disdained today. Gombrowicz (2000: 105) similarly summarizes (in the character of Joey from Ferdydurke) his admiration and helplessness with respect to the phenomenon of aesthetization:

Sixteen years old, in a skirt, sweater, and sneakers, athletic looking, easygoing, smooth, limber, agile and impudent! The sight of her made my spirit and my face freeze in fear. I understood at a glance - here was a powerful presence, probably more powerful than Pimko himself, and equally absolute in her way $(\ldots)$.

By presenting such a suggestive portrait of the Modern Schoolgirl, Gombrowicz moves to the side of the visual culture and presents us with kitsch which is, in fact, an image that is beautiful with some overwhelming power. This kitsch is really charming and, what is worse, stylish, and it is much more dangerous as it seems to really promise the long-lost perfection.

Gombrowicz, so sensitive to the 'second-class' beauty, looks like a prophet of modern aesthetization present in the times of ruthless dominance of mass culture. It seems that the border of the two zones - Maturity and Immaturitybetween which kitsch flows freely (according to the clear division made by Jarzębski ${ }^{15}$ ) is additionally washed by the boundless wave of popular culture. Let us take a look: easy, pleasant and attractive 'art of happiness' no longer has to be naive, and thus stand on the side of Immaturity and Youth. In mass culture, Youth becomes calculated Adulthood and Immaturity accepts the nature of perfect Form - a small, but in a certain sense perfect work of art, like Duchamp's ready-mades, copied images of Marilyn Monroe or Coca-Cola cans. This is the art of today, the times when the Polish word

15 The dichotomous division into the spheres of 'Form and chaos, Maturity and Immaturity, Superiority and Inferiority, Old Age and Youth' (Jarzębski 1996: 55-56). 
'galeria' ('gallery') is commonly associated not with an exhibition of works of art, but a mole, a hypermarket paradise ('galeria handlowa'). The status of products of mass culture as kitsch raises doubts too. Here, I mean gadgets, technological wonders, signs of mass culture which - as Elżbieta Anna Sekuła (2008: 42) writes - are the expression of a modern stance accepting kitsch and have managed to undergo a metamorphosis 'from mediocrity and mass proliferation to professionalism and detailed perfectionism'. Let us notice that it was already anticipated by the 'gadgets' in Zuta Youngblood's room, which made up a peculiar and meaningful set: sneakers + apple + photograph of Fred Astaire and Ginger Rogers + bed with linen + cold shower + telephone. 'How modest yet how powerful!' (Gombrowicz 2000: 156) This is like a layout of Parky Patt from Philip Dick's (2010) novel, which was meant to relieve the troubled heads of cosmos conquerors: a collection of aesthetic dolls with which adults would play, having previously taken special drugs, just like children play with Barbie dolls. Is it still kitsch or is it modern art in the era of common aesthetization? Minimalism, simplification and aesthetics: this attracts the citizen in the times of late modernity, tired of multitude. Gadgets are like idols, objects cast in bronze desired by the Jews, for which we reject the God of great art... Because they are so perfect and shiny. They seem - much more convincingly than the Invisible - to promise wonders.

Jarzębski (1996: 59) claimed that brain-sick searches for hidden meanings and codes related to the character of Youngblood may be interpreted as Gombrowicz's mockery of avant-garde poetry. It seems that there is something more in it: fascination with form, signs whirling in the air, which only denote themselves; life on the surface, which is, however, beautiful and aesthetically refined. This sensitivity to form and signs in Gombrowicz's writings was accurately described in philosophical concepts of the post-modern era: for example Jean Baudrillard (1994) and his concept of simulacrum as an empty sign.

Gombrowicz succumbed to the overpowering aesthetics of mass culture - thus, he succumbed to kitsch. As opposed to Witkacy, faithfully defending his aristocratic tastes, considering radio the peak of barbarity, Gombrowicz at the end of his life acknowledged without embarrassment that he was a lover of cinema and television, that he liked 'almost all films' (Catalucco, Illg 1991: 36). (I remember my great surprise when I was told that Czesław 
Miłosz in his old age loved to watch the Polish television series Złotopolscy). It seems that the author of Ferdydurke was attracted by their predictability, style, unification, finiteness and craft; a 'small perfection' of film genres. Therefore, Gombrowicz succumbed to kitsch, but kitsch of a better quality, denoting not a stereotype, but an 'icon of mass culture', not tackiness (bad execution), but perfection. He succumbed to kitsch ransomed by the hard work of the film producers... but also Zuta with trembling locks, subjecting her body to a cold shower. It is a ready-made and simple kitsch, yet demanding toil and fortitude (like today's fitness celebrities). Simplified and not too sophisticated intellectually, yet full of surprising wisdom, asceticism and discipline (let us notice: clichéd wisdom from the Internet, phrases like: 'It is better to have less than more' acquire value when they are supported by actual physical effort of a dieting celebrity - the saint of modern times).

Therefore, it is possible to create a typology of kitsch with respect to its aesthetic power: from mild kitsch, which may be envied just a bit, and which allows an intellectual to distance himself (how 'nice' is the faiht of Catholics participating in a church fair; how beautifully are the guests dancing at the wedding party; what a sweet girl, Zosia, she will definitely make a good wife), up to powerful phenomena like 'Zuta the Modern' (though not her parents, who are funny just like other Gombrowicz's characters). Kitsch may be just trashy, bad art, which may be mocked by an intellectual (a vulgar-looking girl, disco polo music, garish 'monstrosities'), yet it may also be executed perfectly, enticingly and brilliantly. Just like the American culture, its westerns and musicals, its chewing gum, etc., Gombrowicz could ridicule this 'weak kitsch', but at the same time he was showing that we are becoming more and more helpless with respect to the overpowering, perfect beauty of mass culture products.

\section{Bibliography}

Theodor W. Adorno (1997), Aesthetic Theory, transl. R. Hullot-Kentor, Minneapolis: University of Minnesota Press.

Herman Broch (1969), Notes on the Problem of Kitsch (1950), [in:] KITSCH. An Anthology of Bad Taste, ed. G. Dorfles, London: Studio Vista.

Jean Baurdillard (1994), The Precession of Simulacra, [in:] idem, Simulacra and Simulacion, transl. Sh.F. Glaser, Ann Arbor: University of Michigan Press. 
Francesco M. Cataluccio, Jerzy Illg ed. (1991), Gombrowicz filozof, transl. K. Bielas, F.M. Cataluccio, Kraków: Znak.

Grzegorz Dziamski (1995), Co oznacza formuła 'kryzys estetyki’?, „Kultura Współczesna”, No. 3/4.

Philip K. Dick (2010), The Three Stigmata of Palmer Eldritch, London: Gollancz. Ernest Gellner (1992), Postmodernism, Reason and Religion, London - New York: Routledge.

Witold Gombrowicz (1988), Diary, transl. L. Vallee, Evanston: Northwestern University Press.

Witold Gombrowicz (2000), Ferdydurke, transl. D. Borchardt, New Haven: Yale University Press.

Witold Gombrowicz (2007), A Kind of Testament, ed. R. Roux, transl. A. Hamilton, Champaign: Dalker Archive Press.

Jerzy Jarzębski (1996), Kicz jest w nas: Gombrowicza romans $z$ kiczem, „Teksty Drugie", No. 4.

Dagmara Jaszewska (2002), Nasza niedojrzała kultura. Postmodernizm inspirowany Gombrowiczem, Warszawa: Oficyna Naukowa.

Marek Kwiek (1993), Richarda Rorty'ego postmodernistyczny świat ironii, „Kultura Współczesna”, No. 1.

Jakub Lubelski (2013), Gombrowicz, zrozpaczony konserwatysta, „Pressje”, No. 34. Jakub Lubelski (2015), Ssanie. Głód sacrum w literaturze polskiej, Warszawa: Fundacja Świętego Mikołaja.

José Ortega y Gasset (1932), The Revolt of the Masses, transl. anonymous, New York: W.W. Norton \& Company.

Dwight Macdonald (1953), A Theory of Mass Culture, „Diogenes”, Vol. 1, No. 3. Abraham Moles (1978), Kicz, czyli sztuka szczęścia. Studium o psychologii kiczu, transl. A. Szczepańska and E. Wende, Warszawa: PIW.

Krzysztof Piątkowski (2008), Kicz jako problem antropologiczny, [in:] Kiczosfery wspótczesności, ed. W.J. Burszta, E.A. Sekuła, Warszawa: Academica.

Paweł Rojek (2013), Gombrowicz i Wyszyński, „Pressje”, No. 34.

Richard Rorty (1989), Contingency, Irony and Solidarity, Cambridge: Cambridge University Press.

Stefano Rosso (1983), A Correspondence with Umberto Eco, transl. C. Springer, „Boundary 2”, Vol. 12, No. 1.

Elżbieta Anna Sekuła (2008), Kicz jako źródełko radości, [in:] Kiczosfery współczesności, ed. W. J. Burszta, E.A. Sekuła, Warszawa: Academica. 
Richard Shusterman (1992), Pragmatist Aesthetics: Living Beauty, Rethinking Art, Lanham: Rowman \& Littlefield Publishers.

Andrzej Szahaj (2002), Ironia i miłość. Neopragmatyzm Richarda Rorty'ego w kontekście sporu o postmodernizm, Wrocław: Wydawnictwo Leopoldinum. Wolfgang Welsch (1997), Aesthetics Beyond Aesthetics: Toward a New Form of the Discipline, „Literature \& Aesthetics”, No. 7.

Wolfgang Welsch (1998), Becoming Oneself, http://sammelpunkt.philo.at/198/1/ becoming_oneself.htm.

Stanisław Ignacy Witkiewicz (1980), Unwashed Souls, [in:] idem, Beelzebub Sonata. Plays. Essays. Documents, ed. and transl. D. Gerould and J. Kosicka, New York: PAJ Publications.

\section{Summary}

The authoress of the article continues the searches initiated by Jerzy Jarzębski and discusses the phenomenon of kitsch in the work of Witold Gombrowicz. The study is based on a content analysis of selected fragments of works by this author (especially the novel titled Ferdydurke) and it refers to certain concepts of modernity and postmodernity (W. Welsch, R. Rorty, J. Baudrillard). The writer himself is treated as an original philosopher of modernity (and later postmodernity); on account of this, he was ahead of his time. The work presents the thesis that Gombrowicz may be attributed both the modernist sense of the category of kitsch and its parodical practices, as well as a peculiar tendency for kitsch and a tendency to play with kitsch. This tendency is analyzed in the article as an attitude corresponding to the postmodern condition, especially its characteristic phenomenon called the aesthetization of culture, which was mentioned, among other things, by Wolfgang Welsch (culture of design, gadgets and superficial styling). In this sense, Gombrowicz's philosophy corresponds to the postmodern rehabilitation of kitsch.

Keywords: kitsch, aesthetization of culture, gadget, pop culture, styling of life, postmodernity, modernity, Witold Gombrowicz 